\title{
Bromatological Analysis, Chemical Composition and Bioassays from the Genipa americana L. (Rubiaceae)
}

\author{
Oneil Valerio Ávila ${ }^{1}$, Ismael Montero Fernández ${ }^{2}$, Habdel Nasser Rocha da Costa ${ }^{1,5}$, \\ Antonio Alves de Melho Filho ${ }^{1,2,5}$, Ricardo Carvalho dos Santos $^{3}$ \& Pedro Rômulo Estevam Ribeiro ${ }^{4}$ \\ ${ }^{1}$ Post-Graduate Program in Chemistry, Center for Research and Graduate Studies in Science and Technology, \\ Federal University of Roraima, Paricarana Campus, Boa Vista, RR, Brazil \\ ${ }^{2}$ Postgraduate Program in Biodiversity and Biotecnology (BIONORTE), Campus Cauamé, Boa Vista, RR, Brazil \\ 3 National Postdoctoral Program of CAPES, Associated to the Postgraduate Program in Agronomy of \\ Universidade Federal de Roraima, Campus Cauamé, Boa Vista, RR, Brazil, and to the Brazilian Agricultural \\ Research Corporation, Embrapa, Boa Vista, RR, Brazil \\ ${ }^{4}$ Post-Graduate in Natural Resources Program, Federal University of Roraima, Paricarana Campus, Boa Vista, \\ RR, Brazil \\ ${ }^{5}$ Department of Chemistry, Federal University of Roraima, Paricarana Campus, Boa Vista, RR, Brazil \\ Correspondence: Oneil Valerio Ávila, Postgraduate Program in Chemistry, Federal University of Roraima, \\ Campus Paricarana, CEP 69304-000, Boa Vista, RR, Brazil. E-mail: dragonquest_fly88@hotmail.com
}

Received: December 26, 2017

Accepted: January 15, $2018 \quad$ Online Published: February 15, 2018

doi:10.5539/jas.v10n3p244

URL: https://doi.org/10.5539/jas.v10n3p244

\begin{abstract}
Genipa americana L. well known as genipap, is a tree that is widely distributed throughout the Brazilian territory. The communities appreciate the genipap fruits, since they are used as food; in addition to that, their fruits have numerous seeds that can be used in the production of vegetable oil. This being, in this work inclined to a bromatological study of the genipap fruits and chemical composition and bioassays from vegetable oil seeds. Obtaining the highest percentage of lipids in the seeds that was of $7.08 \%$, the highest percentage of humidity obtained was $74.66 \%$ present in the pulp, the highest amount of carbohydrates was found in the seeds, with a percentage of $79.37 \%$, the highest percentage of ash present was $3.99 \%$ found in the pulp, another parameter analyzed were the proteins mostly present in the seeds with a percentage of $4.45 \%$ and finally the energy value was calculated, being the majority in the seeds with $398.98 \mathrm{Kcal} / 100 \mathrm{~g}$. The fatty acid profile showed the highest percentage for the Linoleic Acid with $61.5 \%$. The greatest inhibition in the antimicrobial assays was for $S$. typhimurium with $42.12 \%$ inhibition. In the tests performed for the inhibition of the enzyme acetylcholinesterase was $14.95 \%$.
\end{abstract}

Keywords: acetylcholinesterase, GC-FID, genipap, microorganisms, nutrients

\section{Introduction}

The Amazon is considered and known as one of the regions suitable for the production of fruits, for its great diversity of native plants that grow and develop (De-Souza, Rossi, Varella, Silveira, \& Souza, 2015). The G. americana is a tree belonging to the family of the Rubiaceae, is present throughout Brazil, naturally, or cultivated, from the Amazon to São Paulo and Mato Grosso, in various forest formations (Lorenzi, 2008; Santana, 2014).

According to Rabbani, Silva-Mann, and Ferreira (2012), G. americana presents an economic importance for the production of food, since its consumed in natura or used for the production of sweets, jellies and liqueurs (Lorenzi, 1992). The fruits have numerous seeds, which are found together in the innermost part of the nucleus (Figueiredo, Maia, Monteiro, \& De-Figueiredo, 1991).

Besides its use as food according to Soares, Sousa, Garrido, and Lima (2012), fruits (peel, pulp and seeds), leaves, roots and stem are used in folk medicine. The fruits have medicinal properties known as inhibitor of bacteria, fungi, algae and protozoa, in addition to presenting high content of mannitol, which is recommended in 
the Caribbean countries in the reduction of high blood pressure (Cordeiro \& Felix, 2014; Lorenzi \& Matos, 2008).

Nutrients are chemical substances, present in food, these provide energy and are used by the body for the functioning of several vital bodily processes and therefore, need to be obtained from food, among them we have minerals, proteins, carbohydrates, lipids and vitamins (Tortara \& Derrickson, 2017).

In the human body, the nutrients fulfill essential functions such as forming part of the enzymatic system that catalyzes metabolic reactions involving proteins, carbohydrates and lipids. The hardness of certain structures such as teeth and bones and many other important functions to keep the body healthy, the necessary amounts of these nutrients can vary in grams, milligrams and even micrograms (Marzzoco \& Torres, 2007).

Fruits are important sources of many nutrients and serve as an integral part of the human diet, as they provide vitamins, minerals, proteins, carbohydrates, lipids and other vital constituents essential for human health (Coolborn, Esther, Akinsola, \& Afolabi, 2016). Therefore, the objective of this work is to perform a bromatological study of the different parts of the genipapo fruit, as well as to determine the fatty acid profile in the oil extracted from its seeds, to characterize the functional groups by infrared and biological activity studies of antibacterial and inhibitory activity of the acetylcholinesterase enzyme due to its importance for the development of new drugs or pesticides.

\section{Method}

\subsection{Plant Material and Extraction of Vegetable Oil}

The genipap fruits were harvested mature, according to Figure 1, in the municipality of Boa Vista-RR (Brazil) in April 2016 at the following coordinate's $2^{\circ} 50^{\prime} 01.5^{\prime \prime} \mathrm{N} 60^{\circ} 42^{\prime} 21.6^{\prime \prime} \mathrm{W}$. They were exsiccated, deposited and identified in the herbarium of the Federal University of Roraima (UFRR), with a voucher number 8797 . The fruits were taken to the Environmental Chemistry Laboratory (LQA), Paricarana campus, in the Nucleus of Research and Postgraduate in Science and Technology (NPPGCT) of the UFRR, which were washed and cleaned with distilled water, then dried and then separated into shell, pulp and seeds. These were weighed and stored in a freezer at $-20{ }^{\circ} \mathrm{C}$ for lyophilization. The lyophilization of the seeds was carried out in a LÍOTOP lyophilizer, model L 101, for 48 hours until complete drying of the material in the Physics and Land Management Laboratory at the Agricultural Sciences Center (LFMSCSA), Cauamé campus of the UFRR. Subsequently, the material was ground in MARCONI® knife mill, sieved until homogenization of the particles between 20-40 Mesh, and then stored under cover of light.

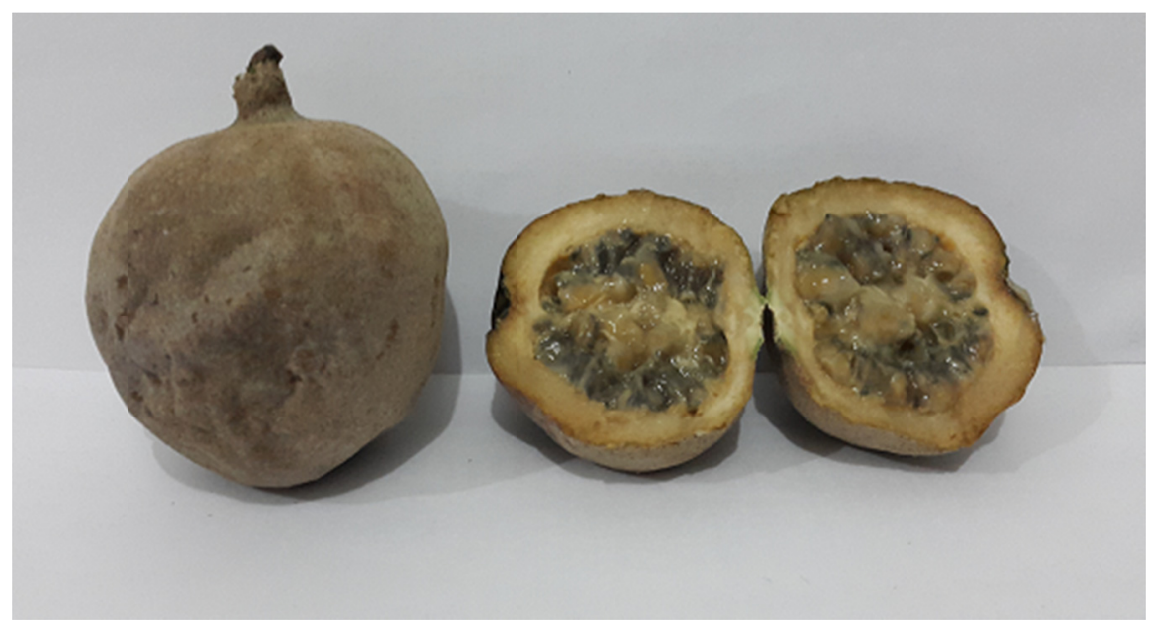

Figure 1. Ripe fruit of G. americana

\subsection{Bromatological Analysis}

The physical chemical parameters evaluated to determine the nutritional composition were the percentage of moisture and ash and the other nutritional parameters evaluated were the determination of total proteins, lipids and carbohydrates to determine the total energy content. 
Humidity was determined by weighing $5.0 \mathrm{~g}$ of fresh sample and placing in pre-weighed porcelain capsules and placed in an air circulation oven for 6 hours at $105^{\circ} \mathrm{C}$ until constant weight, being cooled in a desiccator to room temperature (Instituto Adolfo Lutz [IAL], 2008) and the amount of water was calculated by Equation (1):

$$
\text { Humidity }(\mathrm{g} / 100 \mathrm{~g})=\left(P^{\prime}-P^{\prime \prime}\right) /\left(P^{\prime}-P\right) \times 100
$$

Where, $P=$ weight of the porcelain capsule $(\mathrm{g}) ; P^{\prime}=$ weight of the porcelain dish + fresh sample $(\mathrm{g}) ; P^{\prime \prime}=$ weight of the capsule + sample after drying (g).

For the determination of ashes, the methodology proposed for the food analysis of the (IAL, 2008) with modifications was used, where 5 grams of the lyophilized material placed in porcelain pots previously heated in a $110{ }^{\circ} \mathrm{C}$ air circulation oven were weighed. one hour to remove the moisture and then cooled in a desiccator to room temperature, then the samples were placed in the crucibles and taken to a muffle for calcination of the samples at a temperature of $600{ }^{\circ} \mathrm{C}$ for 12 hours, then the total content was calculated of ash (amount of total minerals) by Equation (2):

$$
\% \text { Ashes }=\frac{N}{M} \times 100
$$

Where, $N=$ mass in grams of ashes; $M=$ mass of the sample in grams.

The vegetable oil was obtained using a Soxlhet extractor with cartridges lined with cotton containing $47 \mathrm{~g}$ (seeds) $30 \mathrm{~g}$ (peel) and $32 \mathrm{~g}$ (pulp) crushed and separated plus $500 \mathrm{~mL}$ of solvent hexane for each extraction (Jorge \& Luzia, 2012 ). The extraction was carried out in a period of 3 hours under reflux of the solvent, then the obtained mixture passed through a separation process using a vacuum roto-evaporator, separating the vegetable oil from the solvent and for calculating the oil yield in accordance with the norm of the Adolfo Lutz Institute (IAL, 2008), Equation (3) was used:

$$
\text { Vegetable oil }(\%)=\frac{N}{P} \times 100
$$

Where, $N$ corresponds to the number of grams of lipid; $P$ corresponds to the number of grams of the sample.

According to the methodology of the Adolfo Lutz Institute, the determination of proteins is obtained from the determination of total nitrogen by Kjeldahl distillation, because the organic matter is decomposed and the existing nitrogen is transformed into ammonium, the content being of nitrogen of the different proteins approximately of $16 \%$, introduces the empirical factor 5.75 (conversion factor for vegetable protein) that will transform the number of grams of nitrogen found with the number of grams of protein (IAL, 2008). Equation (4) presents the calculation to determine the percentage of proteins in the samples:

$$
\text { Proteins }=\% N \times 5.75
$$

The determination of the carbohydrate content was made by the difference of the value 100 subtracted from the sum of the already obtained values of humidity, ashes, lipids and proteins expressed in Equation (5):

$$
\text { Carbohydrates }=100-(\% \text { Humidity }+\% \text { Ash }+\% \text { Lipids }+\% \text { Proteins })
$$

The determination of the energy value was made through the results obtained by the contents of proteins (P), lipids (L) and carbohydrates (C) using Equation (6) that expresses the calculation in Kcal/100 g according to the methodology proposed by the Instituto Adolfo Lutz method (IAL, 2008).

$$
\text { Energy Value }(\mathrm{Kcal} / 100 \mathrm{~g})=(P \times 4)+(L \times 9)+(C \times 4)
$$

Where, $P=$ protein value (\%); $L=$ lipid value (\%); $C=$ value of carbohydrates $(\%) ; 4=$ conversion factor in Kcal determined in calorimetric pump for proteins and carbohydrates; $9=$ conversion factor in Kcal determined in calorimetric pump for lipids.

\subsection{Oil Analysis by GC-FID}

The determination of the fatty acids present in the oil of genipap seeds was made by Gas Chromatography in the chromatography laboratory of the Federal University of Minas Gerais (UFMG), where the samples were hydrolyzed and methylated. A quantity of $12 \mathrm{mg}$ of oil sample in $100 \mu \mathrm{L}$ of a solution of ethanol $(95 \%) /$ potassium hydroxide $1 \mathrm{~mol} / \mathrm{L}(5 \%)$ was dissolved in a cryogenic tube of $2 \mathrm{~mL}$. After vortexing for $10 \mathrm{~s}$, the oil hydrolyzed in a domestic microwave oven (Panasonic NN-ST254W), at a power of $60 \%(420 \mathrm{~W})$, for 6 minutes. After cooling, $400 \mu \mathrm{L}$ of $20 \%$ hydrochloric acid and one tip of the $\mathrm{NaCl}$ spatula $(20 \mathrm{mg})$ and $600 \mu \mathrm{L}$ of ethyl acetate were added. After vortexing for $10 \mathrm{~s}$ and resting for 5 minutes, an aliquot of $300 \mu \mathrm{L}$ was removed from the organic chamber, placed in microcentrifuge tubes and dried by evaporation, thus obtaining free fatty acids (Christie, 1989). Subsequently, the free fatty acids were methylated with $100 \mu \mathrm{L} \mathrm{BF}_{3} /$ methanol (14\%) by 
heating in a $60{ }^{\circ} \mathrm{C}$ water bath for 10 minutes. The methylated fatty acids were extracted with $500 \mu \mathrm{L}$ of hexane and analyzed by Gas Chromatography.

After the preparation of the fatty acids, the analyzes were performed in an HP7820A Gas Chromatograph (Agilent) equipped with a flame ionization detector. Data acquisition program EZChrom Elite Compact (Agilent). A Supelcowax-10 $15 \mathrm{~m} \times 0.2 \mathrm{~mm} \times 0.2 \mu \mathrm{m}$ column (Supelco) was used with a temperature gradient: $120^{\circ} \mathrm{C}, 0$ min, $10{ }^{\circ} \mathrm{C} /$ min up to $250{ }^{\circ} \mathrm{C}$; injector $(1 / 50$ split $)$ at $250{ }^{\circ} \mathrm{C}$ and detector at $260{ }^{\circ} \mathrm{C}$. Hydrogen as a stripping gas $(3.0 \mathrm{~mL} / \mathrm{min})$ and injection volume of $1 \mu \mathrm{L}$. The identification of the peaks was made by comparing Supelco37 fame mix methylated fatty acid standards (Supelco cat no 47885-U).

\subsection{Oil Analysis Bioassay}

The bioassays in the oil of genipap seeds: antimicrobial activity and the bioassay of the inhibitory activity of the enzyme acetylcholinesterase (ACHE) was in the biotechnology and bioassay laboratory of the Federal University of Minas Gerais (UFMG). For the bacterial activity, a pre-inoculum was prepared, in which the microorganisms were transferred from the culture medium where they were stored for test tubes containing $3.0 \mathrm{~mL}$ of culture medium (BHI for bacteria and Sabouraud for yeast). Next, the tubes were incubated in a greenhouse at $37{ }^{\circ} \mathrm{C}$ for $36 \mathrm{~h}$. With the help of a micropipette, $500 \mu \mathrm{L}$ of this pre-inoculum were transferred to test tubes containing sterile distilled water. The tubes were homogenized and the concentration was adjusted to $600 \mathrm{~nm}$ (bacteria) and $530 \mathrm{~nm}$ (yeast), until reaching a transmittance between $74-75 \%$ (bacteria) and $75-76 \%$ (yeast), corresponding to scale 0,5 of McFarland of standard turbidity, that is, $10^{8} \mathrm{CFU} / \mathrm{mL}$, thus obtaining the suspensions of the inocula used in the bioassay.

For the preparation of the work-solution, the samples were previously solubilized in dimethylsulfoxide (DMSO) at a concentration of $12.5 \mathrm{mg} / \mathrm{mL}$. From this solution, an aliquot of $40 \mu \mathrm{L}$ was withdrawn, which was added to $960 \mu \mathrm{L}$ of the culture medium used in the bioassay, obtaining the working solution in the concentration of 500 $\mu \mathrm{g} / \mathrm{mL}$.

The bioassays were performed in 96 microwell plates, in triplicate. In the first well, $200 \mu \mathrm{L}$ of the working solution in the concentration of $500 \mu \mathrm{g} / \mathrm{mL}$ was added. In the following wells, $100 \mu \mathrm{L}$ of culture medium per well was added, followed by serial microdilution (1:1) of the sample solution, so that the concentrations ranged from 250 to $0.98 \mu \mathrm{g} / \mathrm{mL}$. Next, $100 \mu \mathrm{L}$ of the standardized microorganism inoculum was added to each well.

Four controls were carried out: growth control of the microorganism (to verify cell viability); white, which consists of the solution of the sample in the same concentrations evaluated, replacing the inoculum with sterile distilled water; (the work-solution is replaced by a commercial antibiotic) and the sterility control of the culture medium, containing $100 \mu \mathrm{L}$ of culture medium and $100 \mu \mathrm{L}$ of sterile distilled water. The microplates were incubated in a greenhouse at $37{ }^{\circ} \mathrm{C}$ and after 24 hours the plate reader was read at $490 \mathrm{~nm}$ (Zacchino \& Gupta, 2007).

The antibiotics used for the quality control of the tests were ampicillin for bacteria and nystatin for yeast, whose working solutions were prepared as described above for the samples tested.

The samples were tested against the following microorganisms:

- Candida albicans: ATCC 18804 (yeast)

- Staphylococcus aureus: ATCC 29212 (Gram-positive bacteria)

- Bacillus cereus: ATCC 11778 (Gram-positive bacteria)

- Escherichia coli: ATCC 25922 (Gram-negative bacteria)

- Salmonella typhimurium: ATCC 14028 (Gram-negative bacteria)

The bioassay for the inhibition of the activity of the acetylcholinesterase enzyme was carried out in 96-well microplates, to which $50 \mu \mathrm{L}$ of Tris- $\mathrm{HCl}$ buffer $(50 \mathrm{mM}, \mathrm{pH} 8.0), 125 \mu \mathrm{L}$ of 5.5 -were added. dithiobis (2-nitrobenzoic acid)-DTNB ( $3 \mathrm{mM}, 25 \mu \mathrm{L}$ of the sample solution $(10 \mathrm{mg} / \mathrm{mL}$ in DMSO) and $25 \mu \mathrm{L}$ of acetylcholine iodide-ATCI $(15 \mathrm{mM})$ DMSO was used as a negative control and galantamine $(10 \mathrm{mg} / \mathrm{mL}$ in DMSO) as a positive control (standard inhibitor of the enzyme) The absorbance was measured at $405 \mathrm{~nm}$ using a microplate reader, with intervals of 1 minute for eight times, after these readings were added to the wells $25 \mu \mathrm{L}$ acetylcholinesterase enzyme solution $(0.22 \mathrm{U} / \mathrm{mL}$ in buffer) The absorbance were measured again at 1 minute intervals at 10 to $405 \mathrm{~nm}$ (Frank \& Gupta, 2005, Ellman, Courtney, Andres Jr., \& Feathestone, 1961). The percent inhibition was calculated by comparing the absorbance of the samples with the absorbance of the blank using Equation (7): 
$\%$ Inhibition $=100-\frac{\text { Absorbance of the sample with enzyme }- \text { Absorbance of the sample without enzyme }}{\text { Absorbance of the negative control with enzyme }- \text { Absorbance of the negative control without enzyme }} \times 100$

\section{Results and Discussion}

\subsection{Bromatological Analysis of Genipap Fruit}

In this study the highest percentage of moisture was found in the pulp and it was $74.66 \%$ and the lowest percentage was found in the seeds, which was $5.63 \%$ according to Table 1 . In similar studies carried out on genipap pulps, collected in the state of Minas Gerais, reported a humidity percentage of $70.0 \%$ (Pacheco, Paz, Silva, \& Pascoal, 2014), in other studies with genipap pulps collected in the state of Ceará were reported $74.81 \%$ (Figueiredo, Maia, Holanda, \& Monteiro, 1986) and study made with genipap seeds presented a moisture percentage of 5\% (Carvalho \& Nascimento, 2000).

The other nutritional parameter studied was the ashes, which their highest percentage was reported in the pulp with a percentage of $3.99 \%$ and their seeds with a slightly lower percentage of $3.46 \%$ according to Table 1 . Studies made by Pacheco et al. (2014) with genipap pulp collected in the state of Minas Gerais had a percentage of ash of 3.6\%. Other studies made genipap seeds reported a percentage of ash of 1.69\% (Luzia, 2012).

Lipids are natural substances, esters of fatty acids and of an alcohol or a polyol. These perform important biological functions such as: component of the cell membrane, metabolic fuel, skin protective layer, etc. (Bruneton, 2001). They are also used in the food industry, pharmaceutical, as a biofuel (Vianni \& Braz, 1996). In this study, the highest percentage of lipid was obtained from the seeds and was $7.08 \%$ according to Table 1 , a little lower, compared to studies done by other authors on genipap seeds that showed a lipid percentage of $10.39 \%$ (Luzia, 2012).

Proteins are considered to be the most important constituent of living cells, which can be of plant or animal origin and represent the largest chemical group in the body of animals, among some of the main functions of proteins are; essential constituent of all cells, in the growth and development of the body and in the production of metabolic and digestive enzymes (FAO, 2002). In the present work, the highest percentage was found in the seeds with $4.45 \%$ and the pulp the edible part was $3.97 \%$ according to Table 1 , other authors in similar studies with genipap pulps, collected in the state of Minas Gerais they reported a protein percentage of $1.7 \%$ (Pacheco et al., 2014) and in studies made with genipap seeds they reported a protein percentage of $25.33 \%$ (Luzia, 2012).

Carbohydrates are compounds that contain carbon, hydrogen and oxygen in proportions of 6:12:6, these in the metabolism are burned and produce energy, in the human diet are like starch and various sugar, carbohydrates can be divided into monosaccharides, disaccharides and polysaccharides (FAO, 2002). According to the World Health Organization, who suggests that carbohydrates should meet most of the energy needs and that represent between $55 \%$ to $75 \%$ of daily intake and where the intake of fruits and vegetables should reach $400 \mathrm{~g}$ per day (WHO, 2003). In this study, the highest percentage of carbohydrates for seeds was reported with $79.37 \%$.

According to Thompson, Manore, and Vaughan (2008), energy is the fuel our body uses to develop its vital functions, being the Kilocalories (Kcal) the unit in which it is expressed and its recommended daily values vary between 2000 and 2500 calories, depending on age, sex, physiological status and physical activity. In the present study the highest energy value is present in the seeds with $398.98 \mathrm{Kcal} / 100 \mathrm{~g}$ as can be seen in Table 1 , higher compared to the results of studies done by Luzia (2012), with genipap seeds that presented an energetic value of $205.91 \pm 0.13 \mathrm{Kcal} / 100 \mathrm{~g}$, highlighting that in this study they accounted for total dietary fibers.

Table 1. Nutritional analysis of the fruit of G. americana

\begin{tabular}{lllllll}
\hline \multirow{2}{*}{ Genipa americana } & \multicolumn{5}{c}{ Nutritional Contribution } \\
\cline { 2 - 7 } & Humidity (\%) & Ashes (\%) & Lipids (\%) & Carbohydrates (\%) & Proteins (\%) & Energetic Value (Kcal $\left.100 \mathrm{~g}^{-1}\right)$ \\
\hline Pulp & $74.66 \pm 1.41$ & $3.99 \pm 0.25$ & $0.44 \pm 0.02$ & $16.93 \pm 1.20$ & $3.97 \pm 0.03$ & $87.53 \pm 4.83$ \\
Peel & $58.69 \pm 2.41$ & $3.24 \pm 0.36$ & $0.72 \pm 0.12$ & $35.64 \pm 2.71$ & $1.70 \pm 0.01$ & $155.86 \pm 1.25$ \\
Seed & $5.63 \pm 0.09$ & $3.46 \pm 0.09$ & $7.08 \pm 0.38$ & $79.37 \pm 0.42$ & $4.45 \pm 0.02$ & $398.98 \pm 1.71$ \\
\hline
\end{tabular}

\subsection{Fatty Acids Analysis}

According to Bruneton (2001), lipids play an essential role in living organisms as well as in the pharmaceutical industry, food industry as food and other industries such as biofuel. Within nature, palmitic acid, stearic acid, oleic acid and linoleic acid are the four fatty acids that make up $95 \%$ of the acids present in the various types of lipids (Simoês et al., 2007). In this study, of the fatty acids identified linoleic acid (C18:2) was the one with the 
highest percentage of $61.5 \%$ and in the background palmitic acid $(\mathrm{C} 16: 0)$ with $13.1 \%$ according to Figure 2, similar to studies conducted by Figuereido et al. (1991), who presented percentages of $60.5 \%$ and $10.3 \%$ respectively, as can be seen in Table 2 .

Table 2. Profile of G. americana seeds oil fatty acids

\begin{tabular}{lllll}
\hline \multirow{2}{*}{ Fatty Acids } & \multicolumn{2}{c}{ Author } & & Figueiredo et al., 1991 \\
\cline { 2 - 3 } & RT/min & $\%$ & \\
\hline Myristic Acid (C14:0) & 3.9 & 0.1 & - \\
Palmitic Acid (C16:0) & 5.6 & 13.1 & 10.3 \\
Palmitoleic Acid (C16:1) & 5.7 & 0.1 & - \\
Stearic Acid (C18:0) & 7.2 & 9.1 & 9.7 \\
Oleic Acid (C18:1) & 7.4 & 10.7 & 19.5 \\
Linoleic Acid (C18:2) & 7.7 & 61.5 & 60.5 \\
Linolenic Acid (C18:3) & 8.2 & 0.4 & - \\
Arachidonic Acid (C20:0) & 8.9 & 0.2 & - \\
Other & - & 4.8 & - \\
\hline
\end{tabular}

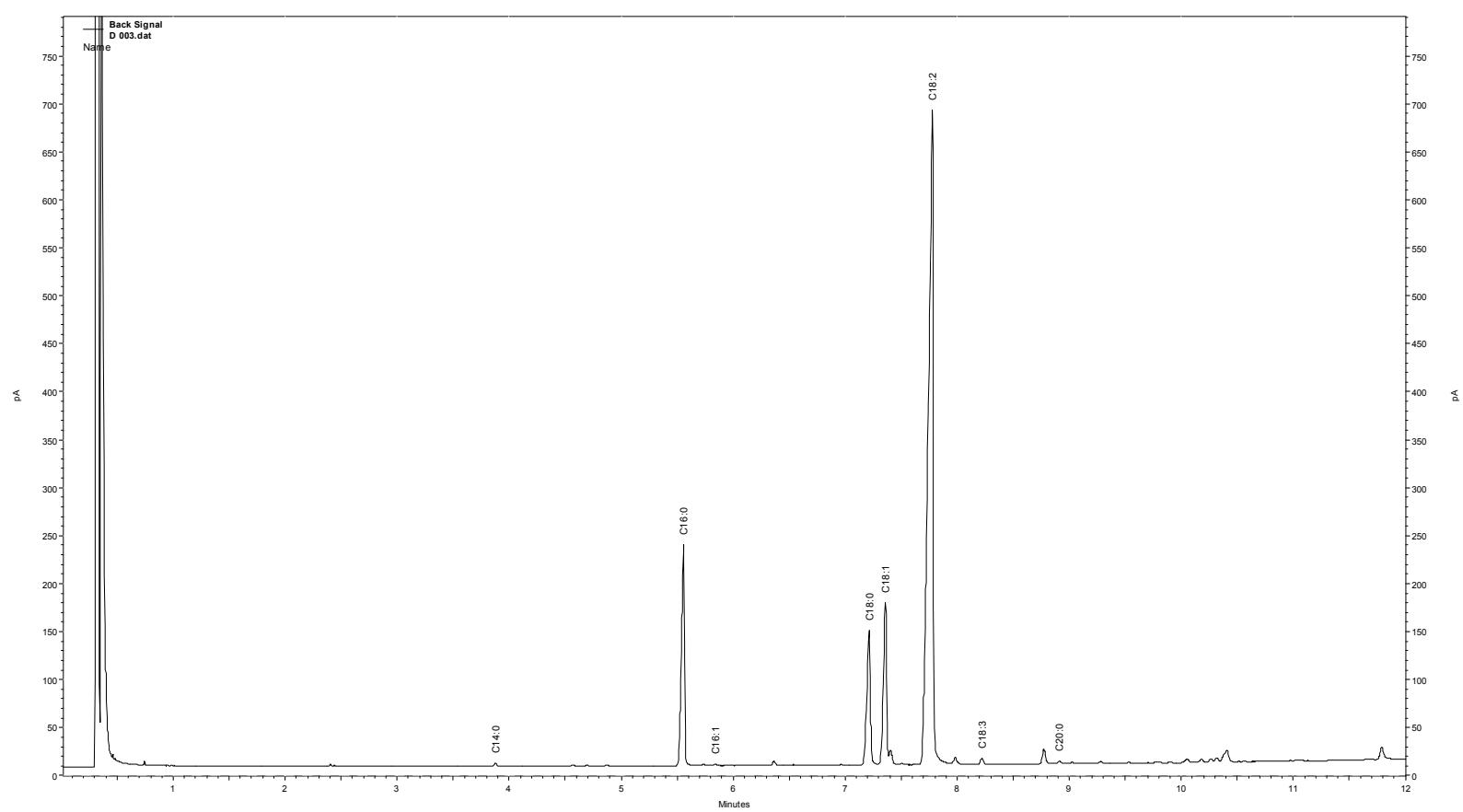

Figure 2. Fatty acids chromatogram

\subsection{Microorganisms Assay}

The bioassays for the antimicrobial activity with the microorganisms tested in this study, as can be seen in Table 3 , had the highest percentage of inhibition for S. typhimurium with $42.12 \%$ inhibition, followed by $B$. cereus with $35.87 \%$ and finally with the lowest percentage of inhibition S. aureus with $34.58 \%$. Studies conducted by Santos et al. (2015), with oil extracted from Annona hypoglauca in the same working conditions, reported a percentage of inhibition of $7.23 \%$ for S. typhimurium and $28.93 \%$ for S. aureus. 
Table 3. Percentage of antimicrobial inhibition at $250 \mu \mathrm{g} / \mathrm{mL}$

\begin{tabular}{llllll}
\hline \multirow{2}{*}{ Sample } & \multicolumn{5}{c}{ Microorganisms } \\
\cline { 2 - 6 } & S. aureus & B. cereus & S. typhimurium & E. coli & C. albicans \\
\hline Seeds oil & $34.58 \pm 11.46$ & $35.87 \pm 11.64$ & $42.12 \pm 2.54$ & 0.00 & 0.00 \\
Ampicillin & $87.85 \pm 6.57$ & $92.60 \pm 0.67$ & $97.90 \pm 4.43$ & $94.37 \pm 4.31$ & - \\
Nystatin & - & - & - & - & $98.17 \pm 6.62$ \\
\hline
\end{tabular}

\subsection{Inhibition of the Activity of the Acetylcholinesterase Enzyme Assay}

The inhibition assay of the acetylcholinesterase enzyme for this study made with the oil extracted from genipap seeds was weak with a percentage of inhibition of 14.95 as can be seen in Table 3 , in comparison with studies done by Santos et al. (2015), under the same conditions with oil extracted from Annona hypoglauca seeds, that showed a percentage of inhibition of $79.55 \%$. That according to Vinutha et al. (2007), who classifies the potential of gross extracts in weak inhibitors if they present a value below $30 \%$, moderate inhibitors those that present 40 to $50 \%$ and potent inhibitors those that show more than $50 \%$.

Table 4. Percentage inhibition values of acetylcholinesterase

\begin{tabular}{lll}
\hline Sample & Seeds oil & Galantamine \\
\hline Inhibition $(\%)$ & $14.95 \pm 2.91$ & $91.71 \pm 0.38$ \\
Coefficient of variance & 0.19 & 0.004 \\
\hline
\end{tabular}

\section{Conclusion}

This work shows the nutritional importance of a fruit that is not yet very considered in the market. The three parts of the same have energetic importance, being the one of smaller contribution the pulp being able to be used for the consumption in natura, as well as for the preparation of jellies, sorbets and another type of snack. In addition, the content of saturated fatty acids in the oil extracted from their seeds should be highlighted, especially linoleic acid, which has the structural and functional importance in the cell, besides being one of the essential fatty acids related to the prevention of certain cardiac diseases.

An important property of this fruit is that the oil of its seeds has antimicrobial and anti-inhibitory applicability of the enzyme acetylcholinesterase, related to Alzehimer's disease.

\section{Acknowledgements}

We are grateful to CAPES for the scholarship received, the Federal University of Minas Gerais, especially the researcher Jacqueline Aparecida Takahashi for biological analysis and Vanny P. Ferraz for analysis of gas chromatography of the oil and group Oleochemicals and laboratory of Physics and soil fertility (NUPAGRI) management UFRR for supporting the development this research.

\section{References}

Bruneton, J. (2001). Farmacognosia, fitoquímica, plantas medicinales (2nd ed.). Zaragosa: Acribia.

Carvalho, J. E. U., \& Nascimento, W. M. O. (2000). Sensibilidade de sementes de jenipapo (Genipa americana L.) ao dessecamento e ao congelamento. Revista Brasileira de Fruticultura, Jabotical, 22(1), 53-56.

Christie, W. W. (1989). Chromatography and Lipids: A Practical Guide. Ayr: The Oil Press.

Coolborn, A. F., Esther, B. B., Akinsola, A. F., \& Afolabi, O. B. (2016). Antioxidant, physicochemical and mineral evaluations of Spondias mombin crude fruit juice. Acta Biologica Szegediensis, 60(2), 171-176.

Cordeiro, J. M. P., \& Félix, L. P. (2014). Conhecimento botânico medicinal sobre espécies vegetais nativas da caatinga e plantas espontâneas no agreste da Paraíba, Brasil. Rev. Bras. Pl. Med., 16(3), 685-692. https://doi.org/10.1590/1983-084x/13_077

De-Souza, M. D. A., Rossi, A. A. B., Varela, T. L., Silveira, G. F., \& Souza, S. A. M. (2015). Stigmatic receptivity and pollen viability of Theobroma subincanum Mart.: Fruit species from the amazon region. Rev. Bras. Frutic., 38(4). https://doi.org/10.1590/0100-29452016757 
Ellman, G. L., Courtney, K. D., Andres Jr., V., \& Featherstone, R. M. (1961). A new and rapid colorimetric determination of acetylcholinesterase activity. Biochem. Pharmacol., 7(2), 88-90. https://oi.org/10.1016/ 0006-2952(61)90145-9

FAO (Food and Agriculture Organization of the United Nations). (2002). Macronutrientes: Carbohidratos, grasas y proteinas (Chapter 9). FAO. Retrieved from http:/www.fao.org/docrep/006/w0073s/w0073s0d. htm\#bm13

Figueiredo, R. W., Maia, G. A., Holanda, L. F. F., \& Monteiro, J. C. S. (1986). Características físicas e químicas do jenipapo. Pesq. Agropec. Bras., Brasilia, 21(4), 421-428.

Figueiredo, R. W., Maia, G. A., Monteiro, J. G. S., \& De-Figueiredo, E. A. T. (1991). Composição de ácidos graxos na fração lipídica da polpa e sementes do jenipapo (Genipa americana, L.). Boletim Centro de Pesquisa de Processamento de Alimentos, 9(2). https://doi.org/10.5380/cep.v9i2.14449

Frank B., \& Gupta, S. (2005). A review of antioxidants and Alzheimer's disease. Ann. Clin. Psychiatry, 17(4), 269-286. https://doi.org/10.1080/10401230500296428

Instituto Adolfo Lutz. (2008). Métodos físico-químicos para análise de alimentos (4th ed.). São Paulo: Instituto Adolfo Lutz.

Jorge, N., \& Luzia, D. M. M. (2012). Caracterização do óleo das sementes de Pachira aquática Aublet para aproveitamento alimentar. Acta Amazônica, 42(1), 149-156. https://doi.org/10.1590/S0044-596720120 00100017

Lorenzi, H. (1992). Árvores brasileiras: manual de identificação e cultivo de plantas arbóreas nativas do Brasil. Nova Odessa: Plantarum.

Lorenzi, H. (2008). Árvores brasileiras: manual de identificação de plantas arbóreas nativas do Brasil (5th ed.). Nova Odessa: Plantarum.

Lorenzi, H., \& Matos, F. J. (2008). Plantas medicinais no brasil, nativas e exóticas (2nd ed.). São Pablo: Plantarum.

Luzia, D. M. M. (2012). Propriedades funcionais de óleos extraídos de sementes de frutos do cerrado brasileiro (Doctoral dissertation, Paulista State University, Brazil).

Marzzoco, A., \& Torres, B. B. (2007). Bioquímica Básica (3th ed.). Rio de Janeiro: Gen.

Pacheco, P., Paz, J. G., Silva, C. O., \& Pascoal, G. B. (2014). Composição centesimal, compostos bioativos e parâmetros físico-químicos do jenipapo (Genipa americana L.) in natura. Demetra, 9(4), 1041-1054. https://doi.org/10.12957/demetra.2014.11310

Rabbani, A. R. C., Silva-Mann, R., \& Ferreira, R. A. (2012). Variabilidade genética de Genipa americana L. pertencente ao baixo curso do rio São Francisco. Revista Árvore, Viçosa-MG, 36(3), 401-409. https://doi.org/10.1590/S0100-67622012000300002

Santana-Neta, L. G. (2014). Caracterização e avaliação do potencial de bioativos e atividade antioxidantes de Genipa americana L. (Master of Science in Food Science, Federal university of Bahia, Brazil).

Santos, R. C., Melo-Filho, A. A., Chagas, E. A., Takahashi, J. A., Ferraz, V. P., Costa, A. K. P., ... Montero, I. F. (2015). Fatty acid profile and bioactivity from Annona hypoglauca seeds oil. African Journal of Biotechnology, 14(30), 2377-2382. https://doi.org/10.5897/AJB2015.14714

Simoês, C. M. O., Schenkel, E. P., Gosmann, G., Melho, J. C. P., Mentz, L. A., \& Petrovick, P. R. (2007). Farmacognosia da planta ao medicamento (6th ed.). Porto Alegre: UFRGS.

Soares, A. C. F., Sousa, C. S., Garrido, M. S., \& Lima, F. S. (2012). Fungos micorrízicos arbusculares no crescimento e nutrição de mudas de jenipapeiro. Revista Ciência Agronômica, 43(1), 47-54. https://doi.org/ 10.1590/S1806-66902012000100006

Thompson, J. L., Manore, M. M., \& Vaughan, L. A. (2008). Nutrition. España: Pearson.

Tortara, G. J., \& Derrickson, B. (2017). Corpo Humano: Fundamentos de Anatomia e Fisiologia (10th ed.). Porto Alegre: Artmed.

Vianni, R., \& Braz-Filho, R. (1996). Ácidos Graxos Naturais: Importância e Ocorrência em Alimentos. Química Nova, 19(4), 400-407. 
Vinutha, B., Prashanth, D., Salma, K., Sreeja, S. L., Pratiti, D., Padmaja, R., ... Deepak, M. (2007). Screening of selected Indian medicinal plants for acetylcholinesterase inhibitory activity. J. Ethnopharmacol, 109, 359-63. https://doi.org/10.1016/j.jep.2006. 06.014

WHO (World Health Organization). (2003). La OMS y la FAO publican un informe de expertos independientes sobre dieta, nutrición y prevención de enfermedades crónicas. Retrieved from http://www.who.int/ mediacentre/news/releases/2003/pr20/es

Zacchino, A. S., \& Gupta, M. P. (2007). Manual de técnicas in vitro para la detección de compuestos antifúngicos (Vol. 85). España: Corpus Editorial.

\section{Copyrights}

Copyright for this article is retained by the author(s), with first publication rights granted to the journal.

This is an open-access article distributed under the terms and conditions of the Creative Commons Attribution license (http://creativecommons.org/licenses/by/4.0/). 